\begin{abstract}
ANNA NADOLSKA-ORCZYK
KAROLINA BARCHACKA

SEBASTIAN GASPARIS

HANNA OGONOWSKA

MACIEJ KALA

Instytut Hodowli i Aklimatyzacji Roślin - Państwowy Instytut Badawczy, Radzików

Kierownik Tematu: prof. dr hab. Anna Nadolska-Orczyk Instytut Hodowli i Aklimatyzacji Roślin -

Państwowy Instytut Badawczy, Radzików, 05-870 Błonie tel. kierownik: 22 7334619; sekretariat:

22 7334658, e-mail: a.orczyk@ihar.edu.pl
\end{abstract}

Prace zostaty wykonane $w$ ramach badan podstawowych na rzecz postęu biologicznego $w$ produkcji roślinnej na podstawie decyzji Ministra Rolnictwa $i$ Rozwoju Wsi nr HOR.hn.802.19.2018, Zadanie 5

\title{
Identyfikacja zmienności genetycznej pszenicy korelującej z potencjałem plonotwórczym i wybranymi cechami systemu korzeniowego
}

\section{Identification of genetic variation of wheat correlating with grain yield and development of root system}

\author{
Słowa kluczowe: aktywność enzymu CKX, ekspresja genów TaCKX, masa korzenia, \\ produktywność, pszenica
}

\section{CEL PODJĘTEGO TEMATU I PROWADZONYCH BADAŃ}

Najnowszy stan wiedzy w temacie genów głównych wpływających na produktywność $\mathrm{i}$ inne ważne cechy agrotechniczne pszenicy i jęczmienia w tym geny $\mathrm{z}$ rodziny $C K X$ przedstawiliśmy w pracy przeglądowej Nadolska-Orczyk i in. (2017). Ich poznawanie i analiza funkcji jest możliwa dzięki rozwijającej się wiedzy dotyczącej genomów, genomiki porównawczej oraz technikom biotechnologicznym umożliwiającym charakterystykę wybranych genów.

W dalszej części tej pracy zebraliśmy informacje na temat charakterystyki/funkcji innych genów głównych istotnie wpływających na produktywność zbóż, zidentyfikowanych i scharakteryzowanych za pomocą najnowszych narzędzi biotechnologicznych. Zostały one sklasyfikowane, ze względu na ich funkcje do grupy: 1) czynników transkrypcyjnych regulujących rozwój kłosa i wpływających na liczbę i wielkość ziarna, 2) genów biorących udział $w$ metabolizmie lub szlakach sygnałowych regulatorów 
wzrostu, 3) genów determinujących podziały i proliferację komórek, głównie modulując wielkość ziarna, 4) regulatorów kwitnienia wpływających na architekturę kwiatostanu i liczbę nasion, 5) genów kontrolujących metabolizm węglowodanów i tym samym wpływających na architekturę roślin i plon ziarna.

Wśród scharakteryzowanych genów biorących udział w metabolizmie cytokinin są geny $C K X$ pszenicy i jęczmienia. Kodują one enzym dehydrogenazę cytokininy (CKX), nieodwracalnie degradujący cytokininy a ich ekspresja i aktywność kodowanego przez nie enzymu jest rozwojowo i tkankowo-specyficzna. Wykazana przez nas ujemna korelacja pomiędzy liczbą nasion oraz ekspresją genów $H v C K X 1$ i $H v C K X 2$ w rozwijających się kłosach jęczmienia (Zalewski i in., 2010, 2012, 2014) świadczyła o silnym wpływie zawartości cytokinin $\mathrm{w}$ określonych organach na produktywność. Podobnie wykazano, że liczba ziarniaków u ryżu była regulowana przez gen z tej samej rodziny $C K X, O s C K X 2$ (Ashikari i in., 2005). W najnowszych badaniach u pszenicy opisano 5 haplotypów genu TaCKX6-D1, z których jeden, TaCKX6-Dla, wykazujący obniżoną $\mathrm{w}$ stosunku do pozostałych ekspresję determinował formowanie większego ziarna o wyższej masie (Lu i in., 2015; Zhang i in., 2012). Dla innego genu z rodziny $T a C K X, T a C K X 4$ wykazano silny związek pomiędzy liczbą kopii a zawartością chlorofilu w liściu flagowym po kwitnieniu i masą ziarna (Chang i in., 2015).

Do innej, ciekawej rodziny genów kontrolujących wielkość ziarna pszenicy należą geny $N A C$ kodujące czynniki transkrypcyjne NAC. Najistotniejszy z nich, $N A M-B 1$ (GpcB1) determinuje przyspieszenie starzenia się roślin, co wpływa na podniesienie jakości białka poprzez zwiększenie zawartości cynku i żelaza (Uauy i in., 2006 a,b). Nadekspresja innego genu z tej rodziny, TaNAC2-5A, wzmacnia wzrost korzeni i poziom akumulacji azotu przez co zwiększa plon ziarna (He i in., 2015).

Celem tegorocznego tematu badawczego jest ocena dziedziczenia znaczników genetyczno/biochemiczno/fizjologicznych produktywności i masy korzenia w przekazanych przez hodowców genotypach/materiałach hodowlanych i poszerzenie puli charakteryzowanych genotypów (ocena minimum $6 \mathrm{~F}_{1}$; poszerzenie puli genotypów minimum 10).

\section{OPIS WYNIKÓW}

Wykonano trzy dalsze krzyżowania niezbędne do oceny minimum 6 mieszańców $F_{1}$ oraz wytypowano na podstawie informacji od hodowców następnych 10 genotypów pszenicy do badań. W uzyskanych mieszańcach i w wytypowanych genotypach przeprowadzono ocenę poziomu ekspresji względnej genów TaCKX1, TaCKX6 i TaNAC2-5A w korzeniach siewek i genu TaCKX1 w dojrzewających kłosach 7 DAP. Dane dotyczące poziomu ekspresji genu TaCKX1 w dojrzewających kłosach (kłosy 7 DAP) pobranych z fitotronu i z pola 10 rodów i odmian z Hodowli Roślin Strzelce Sp. $z$ o.o. Grupa IHAR oraz 6 pokoleń $F_{1}$ przedstawiono $w$ tabeli 1 . Nie stwierdzono istotnej korelacji między ekspresją $T a C K X 1$ w kłosie 7 DAP z fitotronu i z pola. Dane dotyczące oceny poziomu ekspresji genów TaCKX1, TaCKX6 oraz TaNAC2-5A w korzeniach siewek 10 rodów i odmian z Hodowli Roślin Strzelce Sp. z o.o. oraz 6 pokoleń $\mathrm{F}_{1}$ 
przedstawiono $\mathrm{w}$ tab. 2. Stwierdzono istotną statystycznie, silną korelację pomiędzy ekspresją $T a C K X 1$ a $T a C K X 6$ oraz TaNAC2-5A, a także między ekspresją TaNAC2-5A a TaCKX6.

Tabela 1

Ocena poziomu ekspresji genu TaCKX1 w dojrzewających kłosach (kłosy 7 DAP) roślin rosnących w fitotronie i na polu oraz aktywność enzymu CKX 10 rodów i odmian z Hodowli Roślin Strzelce Sp. z o.o. Grupa IHAR oraz 6 pokoleń $F_{1}$ (tylko dla fitotronu)

\begin{tabular}{|c|c|c|c|c|c|c|c|}
\hline Lp. & $\begin{array}{c}\text { Rody i odmiany } \\
\text { z HR Strzelce } \\
\text { oraz } 6 \mathrm{~F}_{1}\end{array}$ & $\begin{array}{c}\text { Ekspresja } \\
\text { TaCKX1, } \\
\text { średnia: } 3 \text { rośl. } \\
\times 3 \text { (FIT.) }\end{array}$ & OS & $\begin{array}{c}\text { Ekspresja } \\
\text { TaCKX1, } \\
\text { średnia: } 3 \text { rośl. } \\
\times 3 \text { (POLE) }\end{array}$ & OS & $\begin{array}{c}\text { Ekspresja } \\
\text { TaCKX1 POLE } \\
\text { + FIT. }\end{array}$ & $\begin{array}{l}\text { Aktywność } \\
\text { względna } \\
\text { POLE/FIT. }\end{array}$ \\
\hline 1 & KOH 1-18 & 0,039 & 0,013 & 0,037 & 0,007 & 0,076 & $1,170 / 0,730$ \\
\hline 2 & $\mathrm{KOH} 2-18$ & 0,060 & 0,016 & 0,038 & 0,008 & 0,099 & $1,411 / 1,766$ \\
\hline 3 & $\mathrm{KOH} 3-18$ & 0,121 & 0,019 & 0,019 & 0,005 & 0,140 & $1,183 / 0,743$ \\
\hline 4 & $\mathrm{KOH} 4-18$ & 0,073 & 0,025 & 0,031 & 0,002 & 0,106 & $1,025 / 1,033$ \\
\hline 5 & KOH 5-18 & 0,127 & 0,014 & 0,026 & 0,006 & 0,153 & $0,753 / 1,183$ \\
\hline 6 & $\mathrm{KOH} \mathrm{6-18}$ & 0,049 & 0,006 & 0,046 & 0,020 & 0,095 & $0,751 / 1,445$ \\
\hline 7 & $\mathrm{KOH} \mathrm{7-18}$ & 0,032 & 0,018 & 0,018 & 0,006 & 0,050 & $0,901 / 0,917$ \\
\hline 8 & $\mathrm{KOH} \mathrm{8-18}$ & 0,078 & 0,029 & 0,055 & 0,009 & 0,133 & $1,171 / 0,825$ \\
\hline 9 & $\mathrm{KOH}$ 9-18 & 0,032 & 0,003 & 0,021 & 0,006 & 0,053 & $1,021 / 1,461$ \\
\hline 10 & $\mathrm{KOH} 10-18$ & 0,082 & 0,011 & 0,026 & 0,007 & 0,108 & $0,725 / 0,662$ \\
\hline 11 & $1 \mathrm{~K}$ & 0,109 & 0,023 & n.t. & n.t. & 0,109 & n.t. $/ 1,283$ \\
\hline 12 & $2 \mathrm{~K}$ & 0,064 & 0,016 & n.t. & n.t. & 0,064 & n.t./1,246 \\
\hline 13 & $3 \mathrm{~K}$ & 0,143 & 0,023 & n.t. & n.t. & 0,143 & n.t. $/ 1,408$ \\
\hline 14 & $4 \mathrm{~K}$ & 0,078 & 0,014 & n.t. & n.t. & 0,078 & n.t. $/ 0,910$ \\
\hline 15 & $5 \mathrm{~K}$ & 0,077 & 0,011 & n.t. & n.t. & 0,077 & n.t./1,609 \\
\hline \multirow[t]{3}{*}{16} & $6 \mathrm{~K}$ & 0,103 & 0,018 & n.t. & n.t. & 0,103 & n.t. $/ 0,880$ \\
\hline & średnia & 0,079 & 0,016 & 0,032 & 0,008 & 0,099 & $1,011 / 1,020$ \\
\hline & OS & 0,034 & 0,007 & 0,012 & 0,005 & 0,032 & $0,228 / 0,362$ \\
\hline
\end{tabular}

W próbkach poddawanych analizie ekspresji genów TaCKX wykonano pomiary aktywności enzymu CKX. Były to kłosy 7 DAP (tab. 1) i korzenie 5-dniowych siewek (tab. 2) pobranych $\mathrm{z}$ rodów hodowlanych/odmian $\mathrm{z}$ HR Strzelce oraz 6 mieszańców $\mathrm{F}_{1}$. Stwierdzono istotną statystycznie korelację między ekspresją TaCKXI w kłosach 7 DAP pobranych $\mathrm{z}$ fitotronu a aktywnością. Zakresy aktywności enzymu $\mathrm{w}$ korzeniach materiałów z HR Strzelce oraz 6 pokoleń $\mathrm{F}_{1}$ (tab. 2) były bardziej zróżnicowane, jednak nie odnotowano korelacji między aktywnością enzymu CKX a ekspresją genów TaCKX1, TaCKX6, TaNAC2-5A.

Następnie przeprowadzono ocenę najważniejszych cech fenotypowych jak masa korzenia 5-dniowych siewek i produktywność. Wyniki masy korzenia 5-dniowych siewek pobranych $\mathrm{z}$ rodów hodowlanych oraz odmian $\mathrm{z}$ HR Strzelce oraz 6 pokoleń $\mathrm{F}_{1}$ zamieszczono w tabeli 2 . Nie stwierdzono wyraźnej korelacji między masą korzenia i ekspresją genów TaCKX6 oraz TaNAC2-5A. Dla genu TaCKX1 wykazano istotną statystycznie korelację z masą korzenia 5-dniowej siewki.

Wyniki innych cech fenotypowych, tj. wysokości roślin, liczby łodyg i kłosów w tym kłosów półpustych, liczby nasion, masy nasion i średniej długości kłosa dla 10 rodów 
i odmian $\mathrm{z}$ HR Strzelce oraz 6 pokoleń $\mathrm{F}_{1}$ były korelowane $\mathrm{z}$ poziomem ekspresji badanych genów. Nie odnotowano istotnych statystycznie korelacji.

Tabela 2

Ocena poziomu ekspresji genów TaCKX1, TaCKX6 oraz TaNAC2-5A, aktywność względna enzymu CKX oraz masa korzenia w korzeniach siewek 10 rodów i odmian z HR Strzelce oraz 6 pokoleń $F_{1}$

\begin{tabular}{|c|c|c|c|c|c|c|}
\hline Lp. & $\begin{array}{c}\text { Rody i odmiany } \\
\text { z HR Strzelce oraz } \\
6 F_{1}\end{array}$ & Masa korzenia $[\mathrm{g}]$ & $\begin{array}{c}\text { Aktywność } \\
\text { względna } \\
\text { FIT. } \\
\end{array}$ & $\begin{array}{c}\text { Ekspresja } \\
\text { TaCKX1 }\end{array}$ & $\begin{array}{c}\text { Ekspresja } \\
\text { TaCKX6 }\end{array}$ & 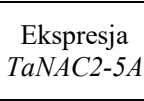 \\
\hline 1 & $\mathrm{KOH} \mathrm{1-18}$ & 0,067 & 1,175 & 0,0039 & 0,0040 & 0,1505 \\
\hline 2 & $\mathrm{KOH} 2-18$ & 0,063 & 2,026 & 0,0058 & 0,0069 & 0,1891 \\
\hline 3 & $\mathrm{KOH} 3-18$ & 0,092 & 1,022 & 0,0030 & 0,0033 & 0,1530 \\
\hline 4 & $\mathrm{KOH} 4-18$ & 0,065 & 1,131 & 0,0024 & 0,0021 & 0,1441 \\
\hline 5 & KOH 5-18 & 0,094 & 0,930 & 0,0048 & 0,0011 & 0,1143 \\
\hline 6 & $\mathrm{KOH}$ 6-18 & 0,090 & 0,990 & 0,0029 & 0,0018 & 0,0018 \\
\hline 7 & $\mathrm{KOH} \mathrm{7-18}$ & 0,086 & 0,953 & 0,0019 & 0,0037 & 0,1323 \\
\hline 8 & $\mathrm{KOH} \mathrm{8-18}$ & 0,073 & 0,759 & 0,0037 & 0,0036 & 0,1210 \\
\hline 9 & $\mathrm{KOH} 9-18$ & 0,084 & 0,539 & 0,0055 & 0,0061 & 0,1225 \\
\hline 10 & KOH 10-18 & 0,076 & 0,690 & 0,0029 & 0,0036 & 0,1180 \\
\hline 11 & $1 \mathrm{~K}$ & 0,039 & 1,019 & 0,0056 & 0,0043 & 0,1626 \\
\hline 12 & $2 \mathrm{~K}$ & 0,066 & 1,015 & 0,0025 & 0,0031 & 0,0326 \\
\hline 13 & $3 \mathrm{~K}$ & 0,053 & 1,228 & 0,0130 & 0,0103 & 0,2346 \\
\hline 14 & $4 \mathrm{~K}$ & 0,055 & 0,920 & 0,0031 & 0,0041 & 0,1317 \\
\hline 15 & $5 \mathrm{~K}$ & 0,054 & 0,938 & 0,0016 & 0,0018 & 0,0468 \\
\hline \multirow[t]{3}{*}{16} & $6 \mathrm{~K}$ & 0,066 & 1,042 & 0,0002 & 0,0003 & 0,0086 \\
\hline & średnia & 0,070 & 1,000 & 0,0039 & 0,0038 & 0,1162 \\
\hline & OS & 0,016 & 0,334 & 0,0028 & 0,0024 & 0,0640 \\
\hline
\end{tabular}

Przeprowadzono również dodatkowe badania ekspresji genów TaCKX2.1 i TaCKX2.2 w kłosach 7 DAP z 30 genotypów rosnących w fitotronie lub na polu, zebranych w 2017 roku. Nie stwierdzono istotnych statystycznie korelacji między ekspresją w kłosie 7 DAP z fitotronu i z pola dla genu TaCKX2.1, TaCKX2.2 oraz pomiędzy nimi (dla fitotronu). Natomiast wykazano wysoką, istotną statystycznie korelację pomiędzy TaCKX2.1 a TaCKX2.2 dla kłosów 7 DAP z pola, która wynosiła $0,70(\mathrm{p}=0,001)$.

\section{WNIOSKI Z PROWADZONYCH BADAŃ}

1. Brak istotnej korelacji pomiędzy ekspresją genu TaCKXI w kłosach zebranych z pola i w kłosach pochodzących z fitotronu świadczy o wpływie środowiska na ekspresję tego genu.

2. Istotna statystycznie, silna korelacja pomiędzy ekspresją genów TaCKX1, TaCKX6 oraz TaNAC2-5A w korzeniach siewek świadczy o silnej koregulacji tych genów.

3. Korelacja ekspresji genu $T a C K X 1 \mathrm{z}$ masą korzenia $\mathrm{z}$ 5-dniowej siewki świadczy o możliwości użycia tego miernika do oceny wzrostu korzeni siewek a tym samym prognozowania produktywności roślin.

4. Brak korelacji między aktywnością enzymu CKX a ekspresją genów TaCKX1, TaCKX6 oraz TaNAC2-5A w korzeniach oraz pozytywna korelacja pomiaru aktywności enzymu CKX w kłosach 7 DAP próbek pochodzących tylko z fitotronu 
jednej hodowli wskazuje na brak możliwości użycia pomiaru aktywności jako markera produktywności.

5. Korelacje ekspresji genów TaCKX1 i TaCKX6 w korzeniu z niektórymi cechami plonotwórczymi wskazują, że mogą one być przydatne jako znaczniki masy korzenia (ekspresja TaCKXI) czy też produktywności (ekspresja TaCKXØ).

6. Silna, istotna statystycznie korelacja między ekspresją genów TaCKX2.1 a TaCKX2.2 w kłosach 7 DAP 12 rodów i odmian z HR Strzelce pochodzących z pola oraz brak istotnej korelacji między tymi genami w badanych genotypach $\mathrm{z}$ fitotronu świadczy o silnej współpracy tych genów w środowisku.

\section{LITERATURA}

Ashikari M., Sakakibara H., Lin S., Yamamoto T., Takashi T., Nishimura A., Angeles E. R., Qian Q., Kitano H., Matsuoka M. 2005. Cytokinin oxidase regulates rice grain production. Science 309: $741-745$.

Chang C., Lu J., Zhang H. P, Ma C. X, Sun G. 2015. Copy number variation of cytokinin oxidase gene Tackx4 associated with grain weight and chlorophyll content of flag leaf in common wheat. PLoS ONE 10:e0145970. DOI:10.1371/journal.pone.0145970.

He X., Qu B., Li W., Zhao X., Teng W., Ma W., Ren Y., Li B., Li Z., Tong Y. 2015. The nitrate-inducible NAC transcription factor TaNAC2-5A controls nitrate response and increases wheat yield. Plant Physiol. 169: 1991 - 2005. DOI:10.1104/pp.15.00568.

Lu J., Chang C., Zhang H. P., Wang S. X., Sun G., Xiao S. H., Ma C. X. 2015. Identification of a Novel allele of TaCKX6a02 associated with grain size, filling rate and weight of common wheat. PLoS ONE 10:e144765. DOI:10.1371/journal.pone.0144765.

Nadolska-Orczyk A., Rajchel I. K., Orczyk W., Onyśk A., Gasparis S. Major genes determining yield-related traits in wheat and barley. (Theor. Appl. Genet. Recenzowane).

Uauy C., Brevis J. C., Dubcovsky J. 2006 a. The high grain protein content gene Gpc-B1 accelerates senescence and has pleiotropic effects on protein content in wheat. Journal of Experimental Botany 57: 2785 - 2794. DOI:10.1093/jxb/erl047.

Uauy C., Distelfeld A., Fahima T., Blechl A., Dubcovsky J. 2006 b. A NAC gene regulating senescence improves grain protein, zinc, and iron content in wheat. Science 314: $1298-1301$.

Zalewski W., Galuszka P., Gasparis S., Orczyk W., Nadolska-Orczyk A. 2010. Silencing of the HvCKX1 gene decreases the cytokinin oxidase/dehydrogenase level in barley and leads to higher plant productivity. J. Exp. Bot. 61: 1839 - 1851. DOI:10.1093/jxb/erq052.

Zalewski W., Gasparis S., Boczkowska M., Rajchel I. K., Kala M., Orczyk W., Nadolska-Orczyk A. 2014. Expression patterns of $H v C K X$ genes indicate their role in growth and reproductive development of barley. PLoS ONE 9:e115729. DOI:10.1371/journal.pone.0115729.

Zalewski W., Orczyk W., Gasparis S., Nadolska-Orczyk A. 2012. HvCKX2 gene silencing by biolistic or Agrobacterium-mediated transformation in barley leads to different phenotypes. BMC Plant Biol. 12: $1-12$.

Zhang L., Zhao Y. L., Gao L. F., Zhao G. Y., Zhou R. H., Zhang B. S., Jia J. Z. 2012. TaCKX6-D1, the ortholog of rice $O s C K X 2$, is associated with grain weight in hexaploid wheat. New Phytol. 195: $574-$ 584. DOI:10.1111/j.1469-8137.2012.04194.x. 
